\title{
STRAŻ MARSZAŁKOWSKA JAKO SŁUŻBA ZMILITARYZOWANA. GENEZA FORMACJI I WYBRANE ASPEKTY PRAWNE
}

W artykule omowiono zagadnienie Straży Marszałkowskiej, która - mimo długiej tradycji - zyskała przymiot służby zmilitaryzowanej dopiero na mocy przepisów ustawy z dnia 26 stycznia 2018 r. o Straży Marszałkowskiej. Charakter prawny formacji pełniących funkcje dzisiejszej Straży Marszałkowskiej był zmienny: początkowo były to jednostki formowane z oddziałów wojska, co sprawiało, że miały one charakter nie tyle zmilitaryzowany, co militarny. Do 2001 r. nie było właściwej regulacji ustawowej, unormowania w tym zakresie były zawarte w regulaminie Sejmu, statucie Senatu, a przede wszystkim w regulaminie organizacyjnym oraz zarządzeniach marszałka Sejmu i szefa Kancelarii Sejmu. Po tym roku aż do uchwalenia ustawy z 2018 r. - jakkolwiek przepisy dotyczące Straży Marszałkowskiej były ujęte w pragmatykach służbowych (ustawa o Biurze Ochrony Rządu, ustawa o Służbie Ochrony Państwa) - strażnicy nie posiadali statusu funkcjonariusza, lecz byli pracownikami Kancelarii Sejmu, do których miały zastosowanie przepisy ustawy z dnia 16 września 1982 r. o pracownikach urzędów państwowych.

Słowa kluczowe: Straż Marszałkowska, służba zmilitaryzowana, ochrona Sejmu i Senatu

\section{MARSHAL'S GUARD AS A MILITARIZED SERVICE. ORIGINS OF THE FORMATION AND SELECTED LEGAL ASPECTS}

In the article the issue of the Marshal's Guard is discussed. Despite a long tradition, the Guard only gained the attribute of a militarized service based on the provisions of the Act of 26 January 2018 on the Marshal's Guard. The legal character of the formations performing the functions of today's Marshal's Guard varied over the years. Initially, they were units formed from military troops, which is why they had rather been military than militarized. Until 2001, the regulations regarding this formation were of non-statutory nature and were contained in the Sejm's regulations, the statute of the Senate, and above all in the Organizational Regulations and decrees of the Marshal of the Sejm and the Chief of the Chancellery. After 2001 - although the provisions regarding the Marshal's Guard were included in the official pragmatics (the act on the Government Protection Bureau, the act on the State Protection Service), the guards did not have the status of an officer, but remained employees of the Sejm Chancellery, to whom provisions of the Act of 16 September 1982 on employees of state offices applied.

Key words: the Marshal's Guard, militarized service, protection of the Sejm and Senate

* Dr Małgorzata Grześków, Uniwersytet Wrocławski, malgorzata.grzeskow@uwr.edu.pl, https://orcid.org/0000-0002-8449-898X

** Dr Mateusz Szymura, Uniwersytet Wrocławski, mateusz.szymura@uwr.edu.pl, https://orcid.org/0000-0001-7146-847 


\section{WPROWADZENIE}

Dnia 26 stycznia 2018 r. została uchwalona ustawa o Straży Marszałkowskiej ${ }^{1}$ [dalej: też SM], która — zgodnie z intencjami ustawodawcy — miała w istotny sposób zmienić status prawny tej formacji. Nie ma wątpliwości, że lakoniczne jak dotąd unormowanie funkcjonowania SM było niewystarczające, zwłaszcza że rola i konieczność podejmowania przez nią działań interwencyjnych zostały potwierdzone dotychczasową praktyką ${ }^{2}$. Niniejsze opracowanie jest próbą ogólnego spojrzenia na SM w świetle obecnych i poprzednio obowiązujących przepisów. Pozostawiając szczegółową analizę statusu prawnego tej formacji szerszym opracowaniom, zasadniczym celem autora artykułu jest przedstawienie jej genezy, statusu ustrojowego, organizacyjnego i kompetencyjnego, a także określenie pozycji zawodowej jej funkcjonariuszy. Przyjęcie takiej metody prezentacji umożliwi osiągniecie zasadniczego celu opracowania, jakim jest potwierdzenie założenia, że w kontekście aktualnej regulacji SM ma charakter formacji zmilitaryzowanej.

\section{GENEZA STRAŻY MARSZALKOWSKIEJ}

Historia straży marszałkowskiej jako formacji ochraniającej — początkowo zgromadzenia stanowe, a następnie parlamentarne — sięga drugiej połowy XVI w., jest więc niewiele krótsza niż historia polskiego parlamentaryzmu ${ }^{3}$. Pierwsze wzmianki o formacji pełniącej rolę współczesnej SM znajdujemy w kronice Marcina Kromera z drugiej połowy XVI w. W swoim dziele Opis Polski autor pisał o osobistej ochronie króla, która podlegała marszałkowi wielkiemu koronnemu i oprócz zapewnienia bezpieczeństwa panującemu gwarantowała również prawidłowy przebieg obrad ${ }^{4}$. Charakter ówczesnych zgromadzeń stanowych (zwoływanych doraźnie) nie wymagał wprowadzenia stałej formacji zajmującej się ochroną sejmów. Z uwagi na brak sił policyjnych w I Rzeczypospolitej całość zadań ochronnych pełniło wojsko, a w szczególności jednostki wojskowe podległe marszałkowi wielkiemu koronnemu ${ }^{5}$, który w ramach jurysdykcji marszałkowskiej wykonywał zarówno wyroki własnego sądu, jak i sądu sejmowego ${ }^{6}$. Do ochrony sejmów wykorzystywano najczęściej żołnierzy

${ }^{1}$ Dz.U. z 2018 r. poz. 729.

${ }^{2}$ Uzasadnienie do projektu ustawy o Straży Marszałkowskiej (druk nr 1971, VIII kadencja Sejmu).

${ }^{3} \mathrm{~W}$ gronie historyków polskiego prawa istnieje spór, czy walor pierwszego sejmu walnego przyznać sejmowi piotrowskiemu z 1468 r., czy sejmowi, który odbył się w tym samym mieście w 1493 r. W. Uruszczak przedstawia poglądy obu grup historyków opowiadając się za pierwszą z tych dat; vide $\mathrm{W}$. Uruszczak, Najstarszy Sejm Walny Koronny „Dwuizbowy” w Piotrkowie w 1468 roku, [w:] Narodziny Rzeczpospolitej: studia z dziejów średniowiecza i czasów wczesnonowożytnych, red. W. Bukowski, T. Jurek, t. 2, Kraków 2012, s. 1033-1056.

${ }^{4}$ M. Kromer, Polonia sive de situ, populis, moribus, magistratibus et re publica regni Polonici libri duo, Kolonia 1577 (dzieło znane jako Opis Polski lub Polska, Kolonia 1577).

${ }^{5}$ W okresie I Rzeczypospolitej jednym z głównych źródeł przepisów porządkowych i karnych były tzw. artykuły marszałkowskie obowiązujące w miejscu przebywania marszałka, które zazwyczaj pokrywało się z miejscem odbywania się Sejmu oraz miejscem pobytu panującego.

${ }^{6}$ J. Czołgoszewski, Powstanie i działalności pierwszego nowoczesnego więzienia w I Rzeczypospolitej, „Lubelski Rocznik Pedagogiczny” 2016, t. XXV, z. 2, s. 150. 
służących w chorągwi węgierskiej marszałka wielkiego koronnego, stąd formacje pełniące zadania straży marszałkowskiej powszechnie nazywano węgrami marszałkowskimi?

W XVII i XVIII w. podstawowe zadania straży marszałkowskiej, czyli zapewnianie porządku i bezpieczeństwa $\mathrm{w}$ miejscu pobytu króla poszerzono o sprawowanie władzy policyjnej w całej Warszawie ${ }^{8}$. Straż marszałkowska była stosunkowo nieliczna9 ${ }^{9}$ nie posiadała również szczegółowo określonego zakresu uprawnień. Do jej podstawowych zadań należała ochrona posiedzeń sejmowych ${ }^{10}$ oraz pilnowanie osób skazanych przez sąd marszałkowski. Straż marszałkowska mogła stosować środki przymusu bezpośredniego, choć nie wobec szlachty ${ }^{11}$. Strażnicy podlegali szczególnej ochronie: uderzenie strażnika karano karą mutylacyjną obcięcia ręki, a zranienie nawet karą śmierci ${ }^{12}$. Mundury węgrów marszałkowskich były szczególnie strojne. Strażnicy byli ubrani w czerwone wierzchnie „suknie”, granatowe kamizelki i spodnie. Za okrycie głowy służyły im kapuzy ${ }^{13} \mathrm{z}$ blaszanymi cyframi odróżniającymi poszczególne chorągwie. Krój stroju strażników był powszechnie wykorzystywany już wcześniej przez „węgrzynów” i „morawców”. W straży marszałkowskiej obowiązywała musztra niemiecka. Strażnicy otrzymywali niewysokie uposażenie, które było podwyższane „komornym od aresztantów, bez których ich kordygarda, osobliwie w czasie sejmu, nigdy nie była [...]"14. Ta charakterystyka uzasadnia twierdzenie, że w okresie I Rzeczpospolitej formacje pełniące funkcje straży marszałkowskiej miały charakter militarny (wojskowy). Były to jednostki wojskowe, którym powierzano zadania związane (przede wszystkim) z zapewnianiem porządku i bezpieczeństwa obrad sejmu oraz ochroną króla.

7 Vide strona internetowa Kancelarii Sejmu, „Straż Marszałkowska”, <http://orka.sejm.gov.pl>, dostęp 3 VIII 2018

${ }^{8}$ Szczególną rolę (pilnowania porządku na polu elekcyjnym) przyznawano straży marszałkowskiej w czasach wolnych elekcji. Sejm walny z 1573 r., zwołany po śmierci Zygmunta II Augusta, zajął się tym tematem przy okazji formułowania spraw „,pokoyu pospolitego” w czasie obierania nowego króla. Również w czasie wolnej elekcji w 1632 r. utrzymanie porządku w trakcie obrad sejmu oraz elekcji powierzono marszałkowi i straży marszałkowskiej, vide J. Malec, Marszałkowie koronni w świetle konstytucji sejmowych z lat 1504-1699. Z badań nad urzędami centralnymi Rzeczypospolitej szlacheckiej, [w:] Nil nisi veritas. Księga dedykowana Profesorowi Jackowi Matuszewskiemu, red. M. Głuszak, D. Wiśniewska-Jóźwiak, Łódź 2016, Łódź 2016, s. 196.

${ }^{9}$ Liczyła ok. 100 osób, w okresie panowania saskiego ich liczba miała wzrosnąć do 150, ibidem.

10 J. Kitowicz, opisując tzw. węgrów marszałkowskich za czasów króla Augusta II, wskazywał, że do ich zadań, oprócz zwyczajnej warty przy kurdygardzie i rontów nocnych należało trzymanie warty przy izbie poselskiej „od rana do nocy”, vide J. Kitowicz, Opis obyczajów za panowania Augusta III, Wirtualna Biblioteka Literatury Polskiej, <https://literat.ug.edu.pl>, dostęp 3 VIII 2018 r.

${ }^{11}$ T. Kucharski, Przepisy porzadkowe na zjazdach elekcyjnych w latach 1587-1674, „Studia Iuridica Toruniensia" 2012, nr 1, s. 92.

12 J. Malec, Marszałkowie koronni w świetle konstytucji sejmowych z lat 1504-1699. Z badań nad urzędami centralnymi Rzeczypospolitej szlacheckiej..., s. 198.

${ }^{13}$ Rodzaj męskiej czapki.

${ }^{14}$ J. Kitowicz, Opis obyczajów... 
Po odzyskaniu przez Polskę niepodległości porządku w Sejmie pilnowała utworzona w 1918 r. Milicja Ludowa rekrutowana spośród członków Pogotowia Bojowego PPS, Polskiej Organizacji Wojskowej i PSL „Wyzwolenia”. Na mocy dekretu z dnia 5 grudnia 1918 r. Tymczasowego Naczelnika Państwa Józefa Piłsudskiego oraz Tymczasowego Rządu Republiki Ludowej Jędrzeja Moraczewskiego — Przepisy o organizacji Milicji Ludowej ${ }^{15}$, została ona uznana za formację policyjną. Jej działalność oceniano jednak negatywnie. Okres Sejmu Ustawodawczego należał do szczególnie burzliwych, dlatego też z inicjatywy marszałka Sejmu Wojciecha Trąmpczyńskiego 8 listopada 1920 r. utworzono pierwszy odział SM, liczący ośmiu strażników ${ }^{16}$. Podstawą do powołania nowej służby był art. 64 regulaminu obrad Sejmu Ustawodawczego ${ }^{17}$, zgodnie z którym władzę policyjną na terenie Sejmu wykonywał wyłącznie marszałek Sejmu poprzez funkcjonariuszy Sejmu oraz mianowanego przez siebie komendanta Straży ${ }^{18}$. W ten sposób po raz pierwszy w historii powołano formację, której wyłącznym zadaniem było pilnowanie porządku w gmachu parlamentu oraz jego ochrona przeciwpożarowa. Straż, która wchodziła w skład Kancelarii Sejmu, w okresie dwudziestolecia międzywojennego nie doczekała się jednak odrębnej regulacji ustawowej.

Po II wojnie światowej SM rozpoczęła działalność w Sejmie Ustawodawczym (lata 1947-1952). W tym okresie formacja należała do Działu Administracyjnego, struktury organizacyjnej Biura Sejmu. Zakres prac Działu Administracyjnego obejmował m.in. czynności związane z pieczą nad porządkiem oraz kierowanie Strażą, która w zakresie pełnienia służby otrzymywała polecenia służbowe bezpośrednio od dyrektora Biura $^{19}$. W tym czasie kompetencje i umundurowanie SM nie przypominały jednak elitarnej formacji sprzed lat, większych podobieństw do tej formacji upatrywano raczej w strażach przemysłowych ${ }^{20}$. W tym okresie Straż działała na podstawie szeregu przepisów wewnętrznych. Jej mundurowy charakter wynikał z $§ 1$ zarządzenia $\mathrm{nr} 3$ Szefa Kancelarii Sejmu z dnia 19 lutego 1974 r. w sprawie organizacji i zasad działania Straż Marszałkowskiej, według którego „Straż Marszałkowska składa sie z z jednolicie umundurowanych pracowników i stanowi jednostkę organizacyjną Kancelarii Sejmu"21. SM miała prawo do użycia broni palnej oraz miotaczy gazu, co z kolei wynikało z instrukcji w sprawie posiadania, używania, ewidencjonowania i przechowywania

15 Dz.P.P.P. z 1918 r. nr 19, poz. 53.

16 Z. Kaczmarek, Wojciech Trąmpczyński, Poznań 1993, s. 125.

17 Regulamin został uchwalony na 2. posiedzeniu Sejmu Ustawodawczego w dniu 14 lutego 1919 r.

18 Do czasu powołania tej formacji władza policyjna miała być wykonywana przez marszałka za pomocą oddanego mu do dyspozycji oddziału wojska.

19 T. Filipczak, Kancelaria Sejmu i Rady Państwa oraz Archiwum w latach [1944]1952-1989, Warszawa 2015, s. 64.

${ }^{20}$ Vide zakładka „Historia Straży Marszałkowskiej” na stronie <http://orka.sejm.gov.pl>, dostęp 3 VIII 2018.

21 Z. Galicki, Propozycja ustawowego umocowania Straży Marszałkowskiej, „Biuletyn Biura Studiów i Ekspertyz" 1995, nr 4, s. 11. 
broni palnej i amunicji oraz ręcznych miotaczy gazu przez strażników (załącznik do zarządzenie nr 22 Szefa Kancelarii Sejmu z dnia 31 sierpnia 1994 r. w sprawie posiadania, używania, ewidencjonowania i przechowywania broni palnej i amunicji oraz ręcznych miotaczy gazu przez strażników Straży Marszałkowskiej) ${ }^{22}$. Brak regulacji ustawowej sprawiał, że w odniesieniu do SM stosowano ${ }^{23}$ przepisy ustawy z dnia 31 stycznia 1961 r. o Straży Przemysłowej ${ }^{24}$. Zdzisław Garlicki, postulując objęcie SM osobną regulacją ustawową, wskazywał przede wszystkim na rodzajowo odmienny od straży przemysłowych charakter formacji oraz konieczność dostosowania uprawnień strażników do nowych rozwiązań przyjętych w ustawie o Policji ${ }^{25}$.

Brak ustawowego uregulowania przepisów dotyczących SM należało oceniać krytycznie nie tylko w uwagi na okoliczność, że podstawę prawną funkcjonowania tej formacji stanowił amalgamat — częściowo już nieaktualnych — aktów prawnych, ale zwłaszcza z uwagi na art. 31 ust. 3 Konstytucji RP z 2 kwietnia 1997 r., w którym ustatuowano zasadę jedynie ustawowego ograniczenia praw i wolności. Wobec charakteru zadań SM nie sposób wykluczyć kolizji między ich wykonywaniem a ograniczeniami konstytucyjnych praw i wolności jednostek.

Umieszczenie regulacji dotyczących SM w ustawie z dnia 16 marca 2001 r. o Biurze Ochrony Rządu [dalej: BOR] ${ }^{26}$, a następnie w ustawie z dnia 8 grudnia $2017 \mathrm{r}$. o Służbie Ochrony Państwa ${ }^{27}$ [dalej: SOP] pozwoliło ustawowo umocować status Straży ${ }^{28}$. Obie ustawy zawierały jednak tylko kilka przepisów odnoszących się bezpośrednio do tej formacji, głównie zawierały one wskazania do odpowiedniego stosowania przepisów regulujących uprawnienia funkcjonariuszy BOR (SOP) do uprawnień przysługującym strażnikom SM.

W ustawie o BOR zdefiniowano Straż Marszałkowską jako umundurowaną formację podległą marszałkowi Sejmu, wykonującą zadania z zakresu ochrony Sejmu i Senatu ${ }^{29}$.

22 Ibidem.

${ }^{23}$ W sposób dorozumiany bądź też wprost, jak chociażby w przypadku instrukcji w sprawie posiadania, używania, ewidencjonowania i przechowywania broni palnej i amunicji oraz ręcznych miotaczy gazu przez strażników Straży Marszałkowskiej (załącznik do zarządzenia nr 22 Szefa Kancelarii Sejmu z dnia 31 sierpnia 1994 r. w sprawie posiadania, używania, ewidencjonowania i przechowywania broni palnej i amunicji oraz ręcznych miotaczy gazu przez strażników Straży Marszałkowskiej), która odsyłała do art. 4 ust. 4 ustawy o Straży Przemysłowej w zakresie prawa do użycia broni.

24 Dz.U. z 1961 r. nr 6, poz. 42. W art. 1 ust. 2 ustawy o Straży Przemysłowej uregulowano jej zadania, przede wszystkim ochronę mienia i zapewnienie bezpieczeństwa. Straż Przemysłowa miała jednolite umundurowanie i była formacją uzbrojoną. W art. 4 wprowadzono szeroki zakres uprawnień strażników, od legitymowania osób znajdujących się na terenie zakładu pracy poprzez dokonywanie rewizji osób i środków lokomocji i zatrzymywanie osób podejrzanych o popełnienie przestępstwa, skończywszy na użyciu — w określonych przypadkach — broni.

25 Z. Galicki, Propozycja ustawowego..., s. 15.

26 Dz.U. z 2001 r. nr 27, poz. 298.

27 Dz.U. z 2018 r. poz. 138.

28 J. Lipski, U. Niewiadomska, K. Zeidler, Ustawa o Biurze Ochrony Rządu. Komentarz, Warszawa 2008.

${ }^{29}$ W ustawie o BOR nie przyznano SM statusu formacji uzbrojonej. 
W ustawie znalazły się regulacje dotyczące zadań SM, wymogów stawianych kandydatom na strażników, zasad przeprowadzania postępowania kwalifikacyjnego, uprawnień i obowiązków strażników oraz organizacji Straży (art. 127-129). Do szczegółowych zadań tej formacji ustawodawca zaliczał m.in.: ochronę obiektów i urządzeń pozostających w zarządzie Kancelarii Sejmu, zapewnienie bezpieczeństwa osób przebywających w obiektach Kancelarii oraz w miejscach odbywania posiedzeń, kontrolę uprawnień do przebywania w tych obiektach, wykonywanie zarządzeń porządkowych marszałka Sejmu wydanych na podstawie regulaminu Sejmu, współuczestnictwo w prowadzeniu działań w zakresie rozpoznania pirotechniczno-radiologicznego w obiektach oraz w podejmowaniu działań zmierzających do neutralizacji zagrożeń w tych obiektach, wykonywanie zadań w dziedzinie obrony cywilnej, konwojowanie wartości pieniężnych, mienia i dokumentów (art. 127 ust. 1 i 3 ustawy o BOR). Zgodnie z art. 127 ust. 3 ustawy o BOR strażnicy SM wykonywali również zadania reprezentacyjne, w szczególności w ceremoniale powitań i pożegnań podczas wizyt parlamentarnych oraz asystach honorowych. Pod względem organizacyjnym SM podlegała marszałkowi Sejmu, w którego zakresie kompetencji było określenie organizacji wewnętrznej oraz szczegółowego trybu działania Straży (art. 129 ust. 3 ustawy o BOR). Przepisy ustawy o SOP (art. 246-250) w zasadzie stanowily powtórzenie dotychczasowych przepisów ustawy o BOR.

Jakkolwiek przepisy dotyczące SM były zawarte w pragmatykach służbowych, strażnicy nie posiadali statusu funkcjonariusza, lecz pozostawali pracownikami Kancelarii Sejmu, do których miały zastosowanie przepisy ustawy z dnia 16 września 1982 r. o pracownikach urzędów państwowych ${ }^{30}$.

Ustawa o Straży Marszałkowskiej, która zaczęła obowiązywać 20 maja 2018 r., znacząco zmieniła status prawny tej formacji. Nastąpiła zmiana pozycji prawnej osób wchodzących w skład Straży, w szczególności poprzez objęcie strażników SM uprawnieniami funkcjonariuszy, określonymi w przepisach ustawy z dnia 18 lutego $1994 \mathrm{r}$. o zaopatrzeniu emerytalnym funkcjonariuszy Policji, Agencji Bezpieczeństwa Wewnętrznego, Agencji Wywiadu, Służby Kontrwywiadu Wojskowego, Służby Wywiadu Wojskowego, Centralnego Biura Antykorupcyjnego, Straży Granicznej, Biura Ochrony Rządu, Państwowej Straży Pożarnej i Służby Więziennej oraz ich rodzin ${ }^{31}$. Ustawa o SM była wzorowana na tzw. pragmatykach służbowych, regulujących stosunek służbowy m.in. w Policji, Straży Granicznej czy Państwowej Straży Pożarnej. Przyjęcie takich wzorców — z uwzględnieniem specyfiki ochrony Sejmu i Senatu — z założenia miało „wykluczyć odrębne rozwiązania ustawowe, w szczególności w zakresie nawiązania, rozwiązania i ustania stosunku służbowego, a także obowiązków i uprawnień funkcjonariuszy" 32 .

${ }^{30}$ Tekst jedn. Dz.U. z 2018 r. poz. 1915. Jeszcze przed wejściem w życie ustawy z dnia 26 stycznia 2018 r. o SM, formacja ta była zaliczana do służb mundurowych; vide W. Maciejko, M. Rojewski, A. Suławko-Karetko, Prawo administracyjne. Zarys wykładu części szczególnej, Warszawa 2011, s. 133-238.

31 Tekst jedn. Dz.U. z 2019 r. poz. 288.

32 Uzasadnienie do projektu ustawy o SM (druk nr 1971, VIII kadencja Sejmu). 


\section{STRAŻ MARSZAŁKOWSKA JAKO SŁUŻBA ZMILITARYZOWANA}

W kontekście prowadzonych rozważań istotna jest możliwość zakwalifikowania SM — działającej na podstawie ustawy z $2018 \mathrm{r}$. — do grona służb zmilitaryzowanych.

Termin „służby zmilitaryzowane” nie jest pojęciem zdefiniowanym w języku prawnym. W systemie brakuje ustawowego określenia podmiotów zaliczanych do tych służ $\mathrm{b}^{33}$. Przedstawiciele doktryny przyjmują założenie powszechnej znajomości tego pojęcia, posługując się nim bez jego definiowania ${ }^{34}$. W literaturze przedmiotu do służb zmilitaryzowanych zalicza się zazwyczaj: Policję, Straż Graniczną, Państwową Straż Pożarną, Służbę Więzienną, Agencję Bezpieczeństwa Wewnętrznego, Agencję Wywiadu, Służbę Kontrwywiadu Wojskowego, Służbę Wywiadu Wojskowego, Służbę Ochrony Państwa, Centralne Biuro Antykorupcyjne, Służbę Celno-Skarbową ${ }^{35}$.

Podobnie niedookreślone są w języku prawniczym pojęcia "służby mundurowe" i „służby militarne”. Przywołane terminy często całkowicie lub częściowo się pokrywają. Służby zmilitaryzowane stanowią kategorię zbiorczą. W jej skład wchodzą formacje o podobnej, choć nie tożsamej specyfice celów i zadań, podobnej strukturze organizacyjnej, wymaganiach stawianych kandydatom do służby, uprawnieniach i obowiązkach funkcjonariuszy, przysługującym im uposażeniu oraz innych świadczeniach pieniężnych ${ }^{36}$. Daną formację można zaliczyć do kategorii służb zmilitaryzowanych na podstawie kryteriów zewnętrznych, jak umundurowanie, posiadanie broni, oraz wewnętrznych, dotyczących sposobu funkcjonowania danej formacji. W literaturze powszechnie przyjmuje się, że specyfika stosunków służbowych funkcjonariuszy służb zmilitaryzowanych przejawia się w szczególnym poświęceniu, jakie jest wymagane przy wykonywaniu służby $^{37}$. Niejednokrotnie na funkcjonariuszach spoczywa obowiązek wykonywania zadań z narażeniem życia i zdrowia. Deklarując gotowość poświecenia dobra indywidualnego na rzecz dobra publicznego, akceptują oni, że w trakcie wykonywania swoich obowiązków będą narażeni na szczególne zagrożenia, których następstwem może być uszczerbek na zdrowiu, a nawet śmierés ${ }^{38}$. Charakter zadań wykonywanych przez funkcjonariuszy służb zmilitaryzowanych decyduje o tym, że interes publiczny chroniony

${ }_{33}$ M. Liwo, Stużby mundurowe jako kategoria języka prawniczego, „Przegląd Prawa Publicznego” 2015, nr 2, s. 9-21.

${ }^{34}$ Stosunek stużbowy w formacjach mundurowych, red. W. Maciejko, P. Szustakiewicz, Warszawa 2015, s. 5.

${ }^{35}$ T. Kuczyński, E. Mazurczak-Jasińska, J. Stelina, System prawa administracyjnego. Stosunek stużbowy, Warszawa 2011, t. 11, s. 5; E. Mazurczak-Jasińska, Wkraczanie prawa pracy w sferę stosunków stużbowych stużb mundurowych - wybrane zagadnienia, „Acta Universitatis Wratislaviensis. Przegląd Prawa i Administracji” 2015, t. C, cz. 1 i 2, s. 653-654; P. Wojtunik, Pojęcie, źródta i przedmiot prawa stosunków slużbowych, „Przegląd Bezpieczeństwa Wewnętrznego” 2013, nr 8, s. 205.

36 Wyrok TK z 19 października 2004 r., sygn. akt K 1/04, OTK ZU 2004/9A/93.

${ }^{37}$ P. Szustakiewicz, Stosunki stużbowe funkcjonariuszy stużb mundurowych $i$ żolnierzy zawodowych jako sprawa administracyjna, Warszawa 2012, s. 22.

${ }_{38}$ M. Wieczorek, Podstawy zatrudniania funkcjonariuszy Centralnego Biura Antykorupcyjnego, $<$ https://zjazd2017.prawopracy.umk.pl>, dostęp 3 VIII 2018. 
przez nich w ramach danej formacji wiąże się z większym ryzykiem oraz poświęceniem niż w przypadku innych zawodów.

Piotr Wojtunik do charakterystycznych cech administracyjnych stosunków służbowych funkcjonariuszy zalicza - oprócz obowiązku poświęcenia - szczególny rodzaj podporząakowania (w tym dyspozycyjność) oraz przyznanie zatrudnionym szczególnych uprawnien ${ }^{39}$. W wyroku z 23 września 1997 r. Trybunał Konstytucyjny wskazał, że specyfika służby w formacjach zmilitaryzowanych przejawia się w obowiązku wykonywania zadań w nielimitowanym czasie pracy oraz trudnych warunkach wymagających narażania życia i zdrowia ${ }^{40}$. W analizowanym orzeczeniu Trybunał podkreślił również rolę ślubowania składanego przez funkcjonariuszy, zgodnie z którym zobowiązują się oni do poświęcenia zdrowia, a nawet życia w imię ochrony wartości nadrzędnych. Przy czym szczególnie istotnym aspektem składania przyrzeczenia jest to, że nie można się uchylić od skutków złożonej przysięgi.

W związku z przedstawionymi uwagami można zadać pytanie, czy z uwagi na status ustrojowy, organizacyjny i kompetencyjny Straży Marszałkowskiej oraz ze względu na status zawodowy jej funkcjonariuszy analizowana formacja może zostać zaliczona w poczet służb zmilitaryzowanych.

Co do zasady kierownicy służb zmilitaryzowanych są jednocześnie centralnymi organami administracji rządowej. Ich zadania polegają na kierowaniu ze szczebla centralnego realizacją zadań administracji ${ }^{41}$. Nadzór nad wykonywaniem tych obowiązków sprawuje prezes Rady Ministrów lub poszczególni ministrowie. Zgodnie z dotychczas obowiązującymi regulacjami wszyscy kierownicy służb zmilitaryzowanych byli powoływani przez prezesa Rady Ministrów na wniosek odpowiedniego ministra. Przykładowo w świetle art. 5 ustawy z dnia 6 kwietnia 1990 r. o Policji [dalej: u.p.] . $^{42}$ komendant główny Policji jest centralnym organem administracji rządowej, właściwym w sprawach ochrony bezpieczeństwa ludzi oraz utrzymania bezpieczeństwa i porządku publicznego. Komendanta głównego Policji powołuje i odwołuje prezes Rady Ministrów na wniosek ministra właściwego do spraw wewnętrznych. Podobnie art. 9 ustawy z dnia 24 sierpnia 1991 r. o Państwowej Straży Pożarnej [dalej: u.p.s.p.] ${ }^{43}$ stanowi, że centralnym organem administracji rządowej w sprawach organizacji krajowego systemu ratowniczo-gaśniczego oraz ochrony przeciwpożarowej jest komendant główny Państwowej Straży Pożarnej powoływany spośród oficerów Państwowej Straży Pożarnej przez prezesa Rady Ministrów, na wniosek ministra właściwego do spraw wewnętrznych. Pozycja prawna komendanta SM jest odmienna. Strażą Marszałkowską kieruje komendant powoływany i odwoływany przez szefa Kancelarii Sejmu (art. 10 ustawy o SM). Komendant SM nie posiada statusu centralnego organu administracji rządowej. Co prawda status taki

39 P. Wojtunik, Pojęcie, źródła i przedmiot prawa..., s. 205.

${ }^{40}$ Wyrok TK z 23 września 1997 r., sygn. akt K 25/96, OTK 1997/3-4/36.

41 A. Górnicz-Mulcahy, Status zawodowy szefów stużb specjalnych. Wybrane elementy, „Acta Universitatis Wratislaviensis. Przegląd Prawa i Administracji” 2015, t. C/1, s. 623-633.

${ }^{42}$ Tekst jedn. Dz.U. z 2019 r. poz. 161.

43 Tekst jedn. Dz.U. z 2018 r. poz. 1313. 
nie należy do cech immanentnie związanych z pojęciem służby zmilitaryzowanejej ${ }^{44}$ jednak rozwiązanie przyjęte przez ustawodawcę świadczy o odmiennej pozycji prawnej tej formacji. O ile dotychczas szefowie wszystkich służb zmilitaryzowanych byli powoływani przez prezesa Rady Ministrów jako przedstawiciela władzy wykonawczej, o tyle szef SM jest od tej władzy niezależny. Pozycja ustrojowa SM zasadniczo wynika z zasad parlamentarnego systemu rządów.

W rozdziale 2 ustawy o SM określono organizację Straży i zasady podporządkowania jej organów. Zgodnie z art. 7 ustawy, SM jest jedną z komórek organizacyjnych Kancelarii Sejmu, której zadania obejmują zapewnienie zaplecza organizacyjno-technicznego i doradczego związanego z działalnością Sejmu i jego organów oraz stworzenie posłom warunków do wykonywania mandatu (art. 199 ust. 1 i 2 regulaminu Sejmu). Struktura wewnętrzna Kancelarii Sejmu odzwierciedla różnorodny charakter jej zadań ${ }^{45}$. Dlatego też Kancelaria Sejmu ani jej szef nie są organami państwa ani Sejmu, a stanowią jedynie zorganizowany aparat urzędniczy obsługujący Sejm ${ }^{46}$. Ustawowe uregulowanie statusu SM jako jednej z komórek organizacyjnych Kancelarii Sejmu - podczas gdy funkcjonowanie pozostałych komórek organizacyjnych uregulowano $\mathrm{w}$ przepisach wewnętrznych — budziła zastrzeżenia już w kontekście ustawy o BOR ${ }^{47}$.

Początkowe przepisy pragmatyk służb zmilitaryzowanych określają charakter danej formacji, np. czy jest ona umundurowana, specjalna, oraz misję, jaką wyznacza jej ustawodawca. Dalsze regulacje określają zadania właściwe dla danej służby. Celem działania formacji zmilitaryzowanych jest zapewnienie państwu i jego obywatelom bezpieczeństwa w sferze militarnej, finansowej, zapobieganie konsekwencjom żywiołów i katastrof oraz ochronę praworządności, a zatem realizację celów określonych w art. 5 konstytucji ${ }^{48}$. Zgodnie z obecnie obowiązującym art. 1 ustawy SM jest umundurowaną i uzbrojoną formacją wykonującą zadania w zakresie ochrony Sejmu i Senatu.

44 Zgodnie z art. 8 ustawy z dnia 16 listopada 2016 r. o Krajowej Administracji Skarbowej (Dz.U. z 2019 r. poz. 768) szef tej formacji nie jest centralnym organem administracji rządowej, a sekretarzem stanu w urzędzie obsługującym ministra właściwego do spraw finansów publicznych. Przed wejściem w życie ustawy z dnia 8 grudnia 2017 r. o SOP, również kierownik BOR nie posiadał statusu centralnego organu administracji rządowej. Mimo to w literaturze przedmiotu przynależność Służby Celno-Skarbowej, a wcześniej również Biura Ochrony Rządu do kategorii służb zmilitaryzowanych nie budzi wątpliwości.

${ }^{45}$ W skład Kancelarii Sejmu wchodzą, oprócz Straży Marszałkowskiej, inne komórki organizacyjne odpowiedzialne za realizację poszczególnych zadań, można m.in.: zapewnienie zaplecza eksperckiego dla legislacji (Biuro Analiz Sejmowych), udostępnianie informacji publicznej oraz informacji o pracy Sejmu (Centrum Informacyjne Sejmu), bieżąca obsługa posiedzeń Sejmu (Sekretariat Posiedzeń Sejmu). Zadania Kancelarii Sejmu nie mają charakteru samodzielnego, nie łączą się również z wykonywaniem władztwa.

46 J.K. Sokołowski, P. Poznański, Wybrane aspekty funkcjonowania Sejmu w latach 1997-2007, Kraków 2008, s. 69.

${ }^{47}$ Opinia prawna Biura Studiów i Ekspertyz Kancelarii Sejmu z 7 lutego 2001 r. do projektu ustawy o BOR, rozdział dotyczący Straży Marszałkowskiej (druk nr 2238, III kadencja Sejmu).

${ }^{48}$ M. Czechowski, Glosa do wyroku Trybunatu Konstytucyjnego z 3 marca 2015 r. (K 39/13) dotyczącego zabezpieczenia społecznego funkcjonariuszy Stużby Celnej, „Praca i Zabezpieczenie Społeczne” 2016, nr 1, s. 37-40. 
Przepis art. 2 ustawy o SM zawiera szeroki katalog zadań tej formacji, wśród których wymieniono m.in.:

1) ochronę terenów, obiektów i urządzeń będących w zarządzie Kancelarii Sejmu i zarządzie Kancelarii Senatu, w tym przy użyciu urządzeń służących do rejestracji obrazu i dźwięku;

2) zapewnienie, w zakresie niezastrzeżonym dla Służby Ochrony Państwa i Żandarmerii Wojskowej, bezpieczeństwa osobom przebywającym na terenach i w obiektach, o których mowa w punkcie 1, oraz w miejscach posiedzeń Zgromadzenia Narodowego, Sejmu i Senatu;

3) kontrolę uprawnień do przebywania na terenach i w obiektach, o których mowa w punkcie 1, oraz wydawanie przepustek uprawniających do przebywania na tych terenach i w tych obiektach, a także zapewnienie tam porządku;

4) prowadzenie rozpoznania pirotechniczno-radiologicznego osób, pojazdów, terenów i obiektów oraz podejmowanie działań zmierzających do neutralizacji zagrożeń;

5) konwojowanie wartości pieniężnych, mienia i dokumentów;

6) udział w wykonywaniu zadań reprezentacyjnych, w szczególności w ceremoniale powitań i pożegnań podczas wizyt parlamentarnych oraz w asystach honorowych.

Z przytoczonej regulacji wynika, że SM nie została utworzona w celu eliminacji fizycznego zagrożenia dla obywateli lub interesów państwa, nie została ona również powołana do walki z klęskami żywiołowymi. Ustawodawca w pierwszej kolejności powierzył SM wykonywanie czynności administracyjno-porządkowych, reprezentacyjnych oraz profilaktycznych. Uprzednio głównym zadaniem Straży było zapewnienie ochrony obiektów należących do Sejmu i Senatu. Dopiero narastająca konieczność podejmowania działań interwencyjnych ${ }^{49}$ poskutkowała przyznaniem tej formacji uprawnień charakterystycznych dla pionu policyjnego.

Na mocy obowiązującej ustawy o SM przyznano jej funkcjonariuszom dużo szerszy niż w poprzednim stanie prawnym - ustawy o BOR i SOP — zakres kompetencji charakterystyczny dla służb zmilitaryzowanych, w tym m.in. prawo używania broni palnej oraz stosowania środków przymusu bezpośredniego ${ }^{50}$. Już w art. 1 ustawy o SM odmiennie od poprzednich regulacji Straż zdefiniowano jako umundurowaną i uzbrojoną formację wykonującą zadania w zakresie ochrony Sejmu i Senatu, podczas gdy w poprzednio obowiązujących ustawach o BOR (art. 127 ust. 2) i SOP (art. 246 ust. 2) w ogóle pomijano kwestię uzbrojenia. Na uwagę zasługuje również sposób wykonywania zadań przez funkcjonariuszy SM „,nawet z narażeniem życia” (art. 20 ustawy o SM). Obecnie zagrożenie dla zdrowia i życia, wynikające z wykonywania obowiązków przez funkcjonariuszy SM, jest zbliżone do zagrożenia płynącego $\mathrm{z}$ pełnienia służby $\mathrm{w}$ formacjach zmilitaryzowanych. Zgonie z art. 20 ustawy o SM, przed podjęciem służby funkcjonariusz SM składa następujące ślubowanie: „Ja, obywatel Rzeczypospolitej

49 Przykładem zagrożeń, z którymi musiała się mierzyć SM, jest m.in. zamach bombowy na budynek Sejmu w 2012 r.

${ }^{50}$ Zgodnie z art. 16 ustawy o SM, w przypadkach określonych w ustawie funkcjonariusze SM mają prawo użycia lub wykorzystania środków przymusu bezpośredniego oraz broni palnej. 
Polskiej, świadom podejmowanych obowiązków funkcjonariusza Straży Marszałkowskiej ślubuję wiernie służyć Narodowi Polskiemu, przestrzegać prawa, dochować wierności konstytucyjnym organom Rzeczypospolitej Polskiej, sumiennie wykonywać obowiązki funkcjonariusza Straży Marszałkowskiej, nawet z narażeniem własnego życia, a także strzec honoru i dobrego imienia służby oraz przestrzegać dyscypliny służbowej i zasad etyki zawodowej”. Złożenie przyrzeczenia stanowi pierwszy akt aktywności służbowej funkcjonariusza, poprzedzający wykonywanie przypisanych mu obowiązków. W SM (podobnie jak w formacjach zmilitaryzowanych ${ }^{51}$ ) osoby pełniące służbę są zobowiązane do dochowania złożonej roty ślubowania, co w odniesieniu do funkcjonariuszy Straży wynika wprost z art. 44 ustawy o SM.

Status zawodowy funkcjonariuszy SM ustalono na wzór i podobieństwo statusu innych służb zmilitaryzowanych. W sytuacji tych podmiotów można dostrzec wszystkie uznawane za znaczące elementy formacji zmilitaryzowanych ${ }^{52}$, takie jak:

1) jednostronne ustalenie przez państwo warunków służby ${ }^{53}$,

2) publicznoprawny charakter służby, czego wyrazem jest administracyjnoprawny akt przyjęcia do służby ${ }^{54}$,

3) trwałość stosunku służbowego ${ }^{55}$,

4) podporządkowanie,

5) dyspozycyjność, poddanie się ograniczeniom i powinnościom wynikającym ze służby ${ }^{56}$ oraz odpowiedzialność dyscyplinarna ${ }^{57}$,

6) przyznanie funkcjonariuszom określonych uprawnień mających niekiedy charakter przywilejów ${ }^{58}$.

${ }^{51}$ Np. wyrok NSA z 8 kwietnia 2008 r., sygn. akt I OSK 642/07, Lex nr 478873; wyrok NSA z 31 października 2008 r., sygn. akt I OSK 1738/07, Lex nr 499920; wyrok NSA z 24 stycznia 2007 r., sygn. akt I OSK 664/06, Lex nr 320415; wyrok Wojewódzkiego Sądu Administracyjnego w Gdańsku z 19 stycznia 2005 r., sygn. akt II SA/Gd 3180/02, Lex nr 698650.

52 T. Kuczyński, Z. Kubot, Z. Masternak, H. Szurgacz, Prawo pracy. Zarys wykładu, Warszawa 2017, s. 371.

${ }^{53}$ Wobec funkcjonariuszy SM przewidziano określone rygory selekcyjne w zakresie obywatelstwa polskiego, korzystania z pełni praw publicznych, posiadania nieposzlakowanej opinii, niekaralności, rękojmi zachowania tajemnicy, stosownie do przepisów o ochronie informacji niejawnych, posiadania co najmniej średniego wykształcenia, posiadania zdolności psychicznej i fizycznej oraz kwalifikacji do pełnienia służby.

${ }^{54}$ Zgodnie z art. 21 ustawy o SM stosunek służbowy funkcjonariusza SM powstaje w drodze mianowania na podstawie dobrowolnego zgłoszenia się do służby.

${ }_{55} \mathrm{~W}$ art. 29 ustawy o SM przewidziano zamknięty katalog przesłanek zwolnienia funkcjonariusza ze służby.

${ }^{56}$ Funkcjonariusz SM nie może być m.in. członkiem partii politycznej ani uczestniczyć w działalności takiej partii lub na jej rzecz, nie może pełnić funkcji publicznej, zrzeszać się w związkach zawodowych, jest zobowiązany uzyskać zezwolenie szefa Kancelarii Sejmu na przynależność do organizacji lub stowarzyszeń krajowych, zagranicznych lub międzynarodowych (art. 47 ustawy o SM).

${ }^{57} \mathrm{Za}$ naruszenie obowiązków służbowych funkcjonariusz ponosi odpowiedzialność dyscyplinarną (art. 100-140 ustawy o SM).

${ }^{58} \mathrm{~Np}$. funkcjonariusze Straży zostali objęci uprawnieniami określonymi w przepisach ustawy z dnia 18 lutego 1994 r. o zaopatrzeniu emerytalnym funkcjonariuszy Policji, Agencji Bezpieczeństwa Wewnętrznego, Agencji Wywiadu, Służby Kontrwywiadu Wojskowego, Służby Wywiadu Wojskowego, 


\section{UWAGI KOŃCOWE}

Choć z historycznego punktu widzenia zasadnicza funkcja SM nie uległa zmianie, to ujęcie uprawnień i zadań strażników w ramy kompleksowej regulacji rangi ustawy stanowi zmianę adekwatną do aktualnych potrzeb. Obowiązująca ustawa z dnia 26 stycznia 2018 r. o SM w porównaniu z poprzednimi regulacjami rozszerza kompetencje tej służby o te, które są charakterystyczne dla formacji zmilitaryzowanych. Nowe zadania SM polegają na: prowadzeniu rozpoznania pirotechniczno-radiologicznego osób, pojazdów, terenów i obiektów Sejmu i Senatu oraz podejmowaniu działań zmierzających do neutralizacji zagrożeń, wykrywanie urządzeń podsłuchowych na terenach, w obiektach i w urządzeniach będących w zarządzie Kancelarii Sejmu i zarządzie Kancelarii Senatu. Omawianą ustawą rozszerzono i skonkretyzowano również zakres uprawnień funkcjonariuszy tej służby o możliwość wydawania poleceń osobom, których zachowanie stwarza lub może stworzyć zagrożenie dla bezpieczeństwa, dokonywania kontroli osobistej, używania środków przymusu bezpośredniego i broni palnej. Mimo niektórych różnic w zadaniach oraz organizacji (w stosunku do służb dotychczas zaliczanych do tego grona) SM można obecnie zaliczyć do służb zmilitaryzowanych.

\section{BIBLIOGRAFIA}

ŹRÓDŁA

Prze pis y

Przepisy o organizacji Milicji Ludowej (Dz.U. z 1918 r. nr 19, poz. 53).

Ustawa z dnia 16 września 1982 r. o pracownikach urzędów państwowych (tekst jedn. Dz.U. z 2018 r. poz. 1915).

Ustawa z dnia 6 kwietnia 1990 r. o Policji (tekst jedn. Dz.U. z 2019 r. poz. 161).

Ustawa z dnia 12 października 1990 r. o Straży Granicznej (tekst jedn. Dz.U. z 2019 r. poz. 147).

Ustawa z dnia 24 sierpnia 1991 r. o Państwowej Straży Pożarnej (tekst jedn. Dz.U. z 2018 r. poz. 1313).

Ustawa z dnia 18 lutego 1994 r. o zaopatrzeniu emerytalnym funkcjonariuszy Policji, Agencji Bezpieczeństwa Wewnętrznego, Agencji Wywiadu, Służby Kontrwywiadu Wojskowego, Służby Wywiadu Wojskowego, Centralnego Biura Antykorupcyjnego, Straży Granicznej, Straży Marszałkowskiej, Służby Ochrony Państwa, Państwowej Straży Pożarnej, Służby Celno-Skarbowej i Służby Więziennej oraz ich rodzin (tekst jedn. Dz.U. z 2018 r. poz. 132).

Ustawa z dnia 18 lutego 1994 r. o zaopatrzeniu emerytalnym funkcjonariuszy Policji, Agencji Bezpieczeństwa Wewnętrznego, Agencji Wywiadu, Służby Kontrwywiadu Wojskowego, Służby Wywiadu Wojskowego, Centralnego Biura Antykorupcyjnego, Straży Granicznej, Biura Ochrony Rządu, Państwowej Straży Pożarnej i Służby Więziennej oraz ich rodzin (tekst jedn. Dz.U. z 2019 r. poz. 288).

Ustawa z dnia 16 marca 2001 r. o Biurze Ochrony Rządu (Dz.U. z 2001 r. nr 27, poz. 298).

Centralnego Biura Antykorupcyjnego, Straży Granicznej, Straży Marszałkowskiej, Służby Ochrony Państwa, Państwowej Straży Pożarnej, Służby Celno-Skarbowej i Służby Więziennej oraz ich rodzin (Dz.U. z 2018 r. poz. 132), która w nowym brzemieniu wejdzie w życie 18 kwietnia 2020 r. 
Ustawa z dnia 8 grudnia 2017 r. o Służbie Ochrony Państwa (tekst jedn. Dz.U. z 2018 r. poz. 138).

Ustawa z dnia 26 stycznia 2018 r. o Straży Marszałkowskiej (Dz.U. z 2018 r. poz. 729).

Orzeczen i a

Wyrok TK z 19 października 2004 r., sygn. akt K 1/04, OTK ZU 2004/9A/93.

Wyrok TK z 23 września 1997 r., sygn. akt K 25/96, OTK 1997/3-4/36.

Wyrok NSA z 8 kwietnia 2008 r., sygn. akt I OSK 642/07, Lex nr 478873.

Wyrok NSA z 31 października 2008 r., sygn. akt I OSK 1738/07, Lex nr 499920.

Wyrok Naczelnego Sądu Administracyjnego z 24 stycznia 2007 r., sygn. akt I OSK 664/06, Lex nr 320415.

Wyrok Wojewódzkiego Sądu Administracyjnego w Gdańsku z 19 stycznia 2005 r., sygn. akt II SA/Gd 3180/02, Lex nr 698650.

\section{PIŚMIENNICTWO}

Czechowski M., Glosa do wyroku Trybunału Konstytucyjnego z 3 marca 2015 r. (K 39/13) dotyczacego zabezpieczenia społecznego funkcjonariuszy Stużby Celnej, „Praca i Zabezpieczenie Społeczne" 2016, nr 1.

Czołgoszewski J., Powstanie i działalności pierwszego nowoczesnego więzienia w I Rzeczypospolitej, „Lubelski Rocznik Pedagogiczny” 2016, t. XXV, z. 2.

Filipczak T., Kancelaria Sejmu i Rady Państwa oraz Archiwum w latach [1944]1952-1989, Kancelaria Sejmu, Warszawa 2015, <https://www.archiwa.gov.pl>.

Galicki Z., Propozycja ustawowego umocowania Straży Marszałkowskiej, „Biuletyn Biura Studiów i Ekspertyz" Kancelaria Sejmu, 1995, nr 6.

Górnicz-Mulcahy A., Status zawodowy szefów stużb specjalnych. Wybrane elementy, „Acta Universitatis Wratislaviensis. Przegląd Prawa i Administracji” 2015, t. C/1.

Kaczmarek Z., Wojciech Trąmpczyński, Lega, Poznań 1993.

Kitowicz J., Opis obyczajów za panowania Augusta III, Wirtualna Biblioteka Literatury Polskiej, 2018.

Kromer M., Polonia sive de situ, populis, moribus, magistratibus et re publica regni Polonici libri duo, [b.o.w.] Kolonia 1577.

Kuczyński T., Mazurczak-Jasińska E., Stelina J., System Prawa Administracyjnego, t. 11, C.H. Beck, Warszawa 2011.

Kuczyński T., Kubot Z., Masternak Z., Szurgacz H., Prawo pracy. Zarys wykładu, Difin, Warszawa 2017.

Lipski J., Niewiadomska U., Zeidler K., Ustawa o Biurze Ochrony Rządu. Komentarz, Wolters Kluwer, Warszawa 2008.

Liwo M., Stużby mundurowe jako kategoria języka prawniczego, „Przegląd Prawa Publicznego" $2015, \mathrm{nr} 2$.

Maciejko W., Rojewski M., Suławko-Karetko A., Prawo administracyjne. Zarys wykładu części szczególnej, C.H. Beck, Warszawa 2011.

Stosunek stużbowy w formacjach mundurowych, red. W. Maciejko, P. Szustakiewicz, C.H. Beck, Warszawa 2015.

Malec J., Marszałkowie koronni w świetle konstytucji sejmowych z lat 1504-1699. Z badań nad urzędami centralnymi Rzeczypospolitej szlacheckiej, [w:] Nil nisi veritas. Księga dedykowana Profesorowi Jackowi Matuszewskiemu, red. M. Głuszak, D. Wiśniewska-Jóźwiak, Wydawnictwo Uniwersytetu Łódzkiego, Łódź 2016, https://doi.org/10.18778/ 8088-187-7.14. 
Mazurczak-Jasińska E., Wkraczanie prawa pracy w sferę stosunków stużbowych stużb mundurowych - wybrane zagadnienia, „Acta Universitatis Wratislaviensis. Przegląd Prawa i Administracji” 2015, t. C, cz. 1 i 2.

Misiuk A., Historia Policji w Polsce od X wieku do wspótczesności, WAIP, Warszawa 2008.

Sokołowski J.K., Poznański P., Wybrane aspekty funkcjonowania Sejmu w latach 1997-2007, Oficyna Wydawnicza AFM, Kraków 2008.

Szustakiewicz P., Stosunki stużbowe funkcjonariuszy służb mundurowych i żotnierzy zawodowych jako sprawa administracyjna, Difin, Warszaw 2012.

Uruszczak W., Najstarszy Sejm Walny Koronny „Dwuizbowy” w Piotrkowie w 1468 roku, [w:] Narodziny Rzeczpospolitej: studia z dziejów średniowiecza i czasów wczesnonowożytnych, t. 2, red. W. Bukowski, T. Jurek, Wydawnictwo Towarzystwa Naukowego Młodych Historyków Societas Vistulana, Kraków 2012.

Wieczorek M., Podstawy zatrudniania funkcjonariuszy Centralnego Biura Antykorupcyjnego, $<$ https://zjazd2017.prawopracy.umk.pl>.

Wojtunik P., Pojęcie, źródła i przedmiot prawa stosunków stużbowych, „Przegląd Bezpieczeństwa Wewnętrznego" 2013, nr 8. 